\title{
Potential of Waste Based Biomass Cogeneration for Malaysia Energy Sector
}

\author{
O. O. Sulaiman ${ }^{\mathrm{a}}$, A.H. Saharuddin ${ }^{\mathrm{b}}$, W.B.Wan Nik \\ a,b,d,e Maritime Technology Department, University Malaysia Terengganu \\ ${ }^{c}$ Marine Technology Department, University Teknologi Malaysia
}

\begin{abstract}
Reuse of waste as source energy remains sustainable energy source for humanity. The processing of waste provide fuels for electricity, heat generation, and transportation fuels environmental advantages in term of energy production that lead to vast reduction in the waste stream, production of valuable byproducts, wasteland reduction and the killing of the pathogens and bacteria that cause disease as well as provision of reliability for food safety and mitigation go Green House Gas release.. The process calorific content of biomass is considered less than fossil fuel, but can be more sustainable by using hybrid cogeneration biomass system for marine system. Recent global political will has provided spill in Malaysia policy to pursue production of renewable energy of modest percentage increase of 20 percent by 2020. This paper present the status of biomass, constrain and the way forward in Malaysia.
\end{abstract}

Keywords: Biomass, energy, sustainability, hybrid, power, Waste, Recycle, Environment

\section{INTRODUCTION}

Human technological energy activities are contributor to climate change and associated consequence. The costs of inaction to avert catastrophic impacts is greater than expected, require action can be achieved by moving rapidly to transform the global energy system. According to UN (cf. IPCC 2007: 13), sustainability requirement can be solved through renewable energy, energy conservation and energy efficiency and associated quarto balance of cost, development, social, and environmental preservation and community participation (government's consumers, industry. Adopting new energy system will make a lot of difference large number of people integrating hybrid of hydrogen and solar couple with bioenergy into the existing system will be a good way for the community to adapt to new emerging clean energy concept $[1,2]$.
The search for new source of energy to mitigate threat of climate change is becoming an urgent matter. New knowledge and technology have emerged. And race is on for the choice of the best. There is no drain in this planet; the waste got nowhere to go, but to return back to the system with consequential environmental damage, contamination of rivers, estuarine and the ocean and landfill and associated degradation as well as cost treatment. The greatest challenge for humanity lies in recycling waste for production of energy.

Sources of alternative energy are natural for their zero carbon. There has been a lot of research about the use of free fall energy from the sun to the use of reverse electrolysis to produce fuel cell. For one reason or the other these sources of energy are not economical to produce. Most of the problems lie on efficiency and storage capability. Early human civilization use nature facilities of soil, inland waterways, waterpower which are renewable for various human needs. Modern technology eventually replaces 
renewable nature with non renewable sources which requires more energy and produces more waste. Energy, Economic and Efficiency (EEE) have been the main driving force to technological advancement in shipping. Environmental problem linkage to source of energy poses need and challenge for new energy source. The paper discuss risk based iterative and integrative sustainability balancing work required between the 4 Es in order to enhance and incorporate use of right hybrid combination of alternative energy source (Biomass, solar and hydrogen) with existing energy source (steam diesel or steam) to meet marine system energy demands (port powering).

Since most alternatively energy cannot currently stand alone, Hybrid use of alternative source of energy remains the next in line for the port and ship power. Public acceptability of hybrid energy will continue to grow especially if awareness is drawn to risk cost benefit analysis result from energy source comparison and visual reality simulation of the system for effectiveness to curb climate change contributing factor, price of oil, reducing treat of depletion of global oil reserve. Malaysia tropical climate with reasonable sunlight fall promise usage of source of sun hybrid candidate energy, also hydrolysis from various components to produce fuel cell and hybridization with conventional system and combined extraction of heat from entire system seem very promising to deliver the requirement for future energy supply.

This paper discuss case study of Malaysia biomass renewable energy, available source of energy today, evolution of alternative energy, especially policy change due to the needs of the time and the barrier of storage requirement, system matching of hybrid design feasibility, regulations consideration and environmental stewardship. The paper also discusses holistic assessment requirement, stochastic evaluation, using system based doctrine, recycling and integrated approach to produce energy. Also discuss is the road ahead for Malaysia in the use of bioenergy. The paper hope to contribute to the ongoing strives towards reducing green house gases, ozone gas depletion agents and depletion of oxygen for safety of the planet in order to sustain it for the right of future generation.

\section{ENERGY, ENVIRONMENT AND SUSTAINABLE DEVELOPMENT}

. Sustainable design can be described as system work that which enhances ecological, social and economic well being, both now and in the future. The global requirement for sustainable energy provision is become increasingly important over the next fifty years as the environmental effects of fossil fuel use become apparent.

Various measures must be taken to reduce emission targets. The current reliance on fossil fuels for electricity generation, heating and transport must be greatly reduced, and alternative generation methods and fuels for heating and transport must be developed and used. As new and renewable energy supply technologies become more cost effective and attractive, a greater level of both small scale and large scale deployment of these technologies will become evident. Currently there is increasing global energy use of potential alternative energy supply system options, complex integration and switching for design requirement for sustainable, reliable and efficient system. The issues surrounding integration of renewable energy supplies need to be considered carefully.

\section{CURRENT USE OF RENEWABLE ENERGY}

Renewable energy development and supply are in small-scale, particularly on islands and in remote areas, where the import of energy sources through transport, pipeline or electricity grid is difficult or expensive. Individual buildings, industries and farms are also looking to the possibility of energy self-sufficiency to reduce fuel bills, and make good use of waste materials which are becoming increasingly 
difficult and expensive to dispose of various studies have been carried out into the extensive use of new and renewable resources, to generate electricity, on a small scale, for rural communities, grid-isolated islands and individual farms. Recent studies focus on:

i. Security of supply: where consideration is given to intermittent sources, demand and supply must be as well matched as possible, and this is generally a function of climate. Available supply sources should be considered in order to find the best possible correlation between demand and supply.

ii. Hybrid with conventional system: where energy limited sources used as spinning reserve for times when the intermittent supply does not meet the demand. If this type of spinning reserve is not available, the need for adequate electricity storage was shown to be an important consideration, especially in smaller scale projects.

There are many possible supply combinations that can be employed, and the optimum combination for a given area depends on many factors. The balances being considered can be complex, and this highlights the need for a decision support framework through which the relative merits of many different scenarios and control strategies for a chosen area can be quickly and easily analyzed [2].

The intermittent nature of most easily exploited sources of alternative energy remains the major problem for the supply the electricity network. This has implications for the management of this transitional period as the balance between supply and demand must be maintained as efficiently and reliably as possible while the system moves towards the ultimate goal of a $100 \%$ renewable energy supply over the next fifty to one hundred years. It important to take the of amount intermittent electricity sources that can be integrated into a larger-scale electricity supply network into consideration. Figure 1 shows current use of renewable energy in Malaysia and where biomass stand.

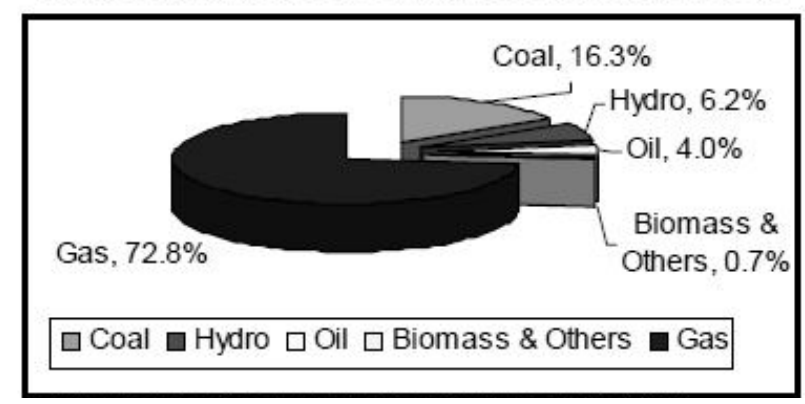

Figure1: Current use of renewable energy in Malaysia, [1]

Excess supply could be supplied by plant run on fuels derived from biomass and waste. The renewable hybrid age require utilities, local authorities and other decision makers to be able to optimization that beat constraints, potentials, and other energy requirements from port powering. When intermittent electricity generating sources are used in a sustainable energy supply system, it is important to consider how well the profiles of demand and supply of electricity match. It is advisable to seek the best possible match by using varying amounts of a range of different intermittent sources. It is prudent to use as diverse a mix of generators as possible [3].

\section{BIOMASS DEVELOPMENT TREND AND BEST PRACTICE IN MALAYSIA}

Malaysia Population is 25.58 million people, with GDP of RM 250 billion in 2004 and GDP per capita of RM9, 732. Malaysia is committed to sustainable development to become a developed country by 2020 . Energy development is a significant part of sustainable development and crucial to success of industrialization process. Approved application for biomass energy project is 21 with total potential grid connection estimated at $139 \mathrm{MW}$. 
Figure 2 shows composition of solid waste for biomass in Malaysia.

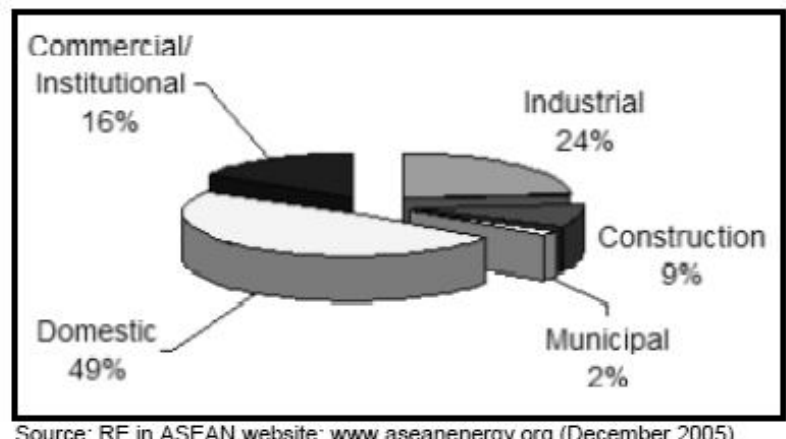

Figure 2: Composition of municipal solid waste in Malaysia

Malaysia energy development problem being addressed include alternative energy. Electricity accounts for about $18 \%$ of the total final energy consumption in Malaysia. Presently, this form of energy is generated using natural gas (71\%), diesel oil (1\%), fuel oil (7\%), hydro (12\%) and coal (9\%). The reported electricity generation in the country does not account for the electricity that is self-generated by industries. In 1999, the total installed power generation capacity in all of Malaysia was $13.632 \mathrm{GW}(11.975 \mathrm{GW}$ in Peninsular Malaysia and $1.657 \mathrm{GW}$ in Eastern Malaysia). The power demand in Peninsular Malaysia was $8.82 \mathrm{GW}$ while in Eastern Malaysia it was $0.871 \mathrm{GW}$. Projections show that electricity demand in the country will grow by 6$10 \%$ annually during the next 5 years, and it will be necessary to plan new generation capacity $[4$, $5]$.

Malaysia electricity supply industry is in the process of being restructured. The Government is re-looking at the numerous options available to ensure it puts in place the most optimal and suitable structure in light of recent experiences in other countries. The restructuring has no specific time frame set at the moment. TNB is now divesting its share of power generation, and eventually its monopoly in distribution will be broken but it intends to retain control of transmission.

With the recent introduction of a grid system operator and a future power market pool, there will be significant changes in the electricity supply industry. This is a long-term strategy being envisaged for the power industry, but with no specific time frame set at the moment. The government is presently considering adoption of $\mathrm{EE}$ and RE as the fifth fuel for electricity generation. Hence, this project will play an important role in providing the learning curve for pragmatic policy support to be instituted by the Ministry. Table 1 depict conventional energy reserve in Malaysia $[6,7,8]$.

Table 1: Malaysia Conventional Energy Reserve in 2004

\begin{tabular}{|l|l|}
\hline & \multicolumn{1}{|l|}{ Oil reserve: } \\
\hline barrels \\
\hline Gas reserve & 2.46 trillion cu m \\
\hline Coal reserve & $\begin{array}{l}1,483 \quad \text { million } \\
\text { tonnes }\end{array}$ \\
\hline $\begin{array}{l}\text { Hydropower } \\
\text { reserve }\end{array}$ & \multicolumn{1}{|c|}{ MW } \\
\hline Biomass & $\begin{array}{l}2 \text { million tonne of } \\
\text { oil equivalent }\end{array}$ \\
\hline Mini-hydro & 1,640 MW \\
\hline
\end{tabular}

\section{SOURCES OF BIOMASS ENERGY IN MALAYSIA}

Biomass fuels consist of both woody and non-woody biomass. The first come from trees and shrubs, the latter from crop residues and other vegetation. Both can be converted into charcoal. In Malaysian economies, important biomass fuels are wood and residues from coconut, rubber and oilpalm trees, as well as sawdust, biogases and 
husks and straw from rice plants. They are used in both traditional and modern applications. Figure 3 shows sources available for Malaysia renewable energy.

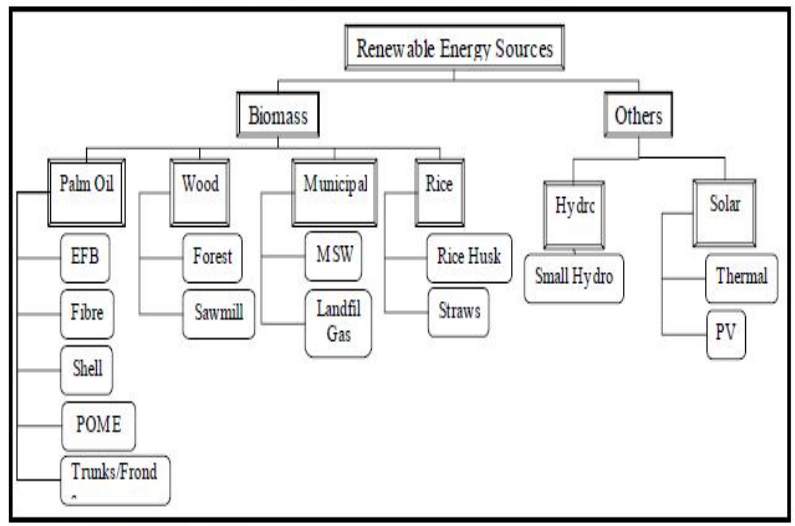

Figure 3: Malaysia renewable energy source

Source: Pusat Tenega Malaysia, 2003

Recent year has seen increases in the use of conventional energy like oil, coal and electricity by an average annual growth rate of $7 \%$. The challenge of global warming and impact on climate has fueled acceptability across humanity driving force use of renewable energy. Biomass has been living source of energy in human civilization, thus, the share of biomass energy in total energy consumption has been decreasing for most countries, due to substitution by modern energy source[9].

In reality, conventional energy is mostly used for new applications such as new industries, transport and household electricity, whereas wood and other biomass continue to dominate in domestic activities such as cooking and in many traditional industries. Biomass energy includes fuelwood, charcoal and agriculture residues used as fuel. In Malaysia biomass is an important energy source, consumption increased on average 2\% per year between 1985 and 1994, due to population growth. Population growth has been used lately to forecast use of biomass, yet, due to lack of data to validate the trend, policy regarding biomass has not been solidified. But lately the
Government has made a giant step to encourage the use of waste derived biomass in Malaysia.

Forest and non-forest sources produce woodfuels by the felling of trees which have grown naturally, or trees which were raised on single or multi-purpose plantations (i.e. as the main products of dedicated woodfuel plantations or as by-products of non-industrial plantations). Alternatively, woodfuels are obtained as lops and tops from forest harvesting; as dead wood, fallen branches, twigs and dead stumps at site; as byproducts of wood-based industries (e.g. waste and scrap wood, sawdust); as surplus non-commercial wood derived from land clearing; or as recovered wood from replacement or demolition of old structures and constructions (e.g. wood from old poles, posts, buildings, scaffolding).

The latter are used mostly by the urban poor.Other biomass Agro residues like rice husk and straw, coconut husk and shells, palmoil kernel shells and fibre, and bagasse are the other main sources of biomass fuels. They are important for both the domestic and the industrial sectors. The forest source is one of many sources of woodfuel production. It consists of government - owned and managed natural forests and tree plantations. However, this is not the only or even the main source. In Malaysia non-industrial plantations of different types (e.g. coconut, rubber and oilpalm plantations, fruit orchards, and trees in homesteads and homegardens) have gained recognition as important sources of woodfuel supply. These non-forest sources, managed and operated mostly by the private sector as informal business enterprises, are gaining prominence in supplying traded woodfuels to markets.

In Malaysia the energy balance shows that bagasse and rice husk accounted for $15-16 \%$ in 1990. These amounts are basically consumed in the industrial sector (palmoil, coconut, sugar and rice milling). Data for the domestic sector are often not available, but evidence from limited surveys indicates that biomass in the form of residues plays an important role, in particular in 
areas where wood as a source of energy is in short supply[10,11].

More than 70 million tonnes annually Production of biomass throughout the year with high sunlight intensity/time and high rainfall Main contributor of biomass. Figure present biomass reseources map in Malaysia.

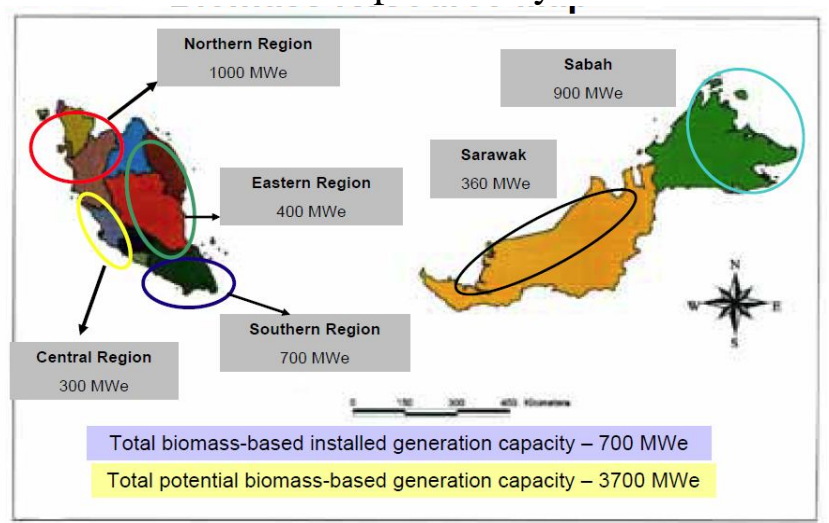

Figure 4: Biomass resource map

Palm predominatly cover $94 \%$ of the sources while wood is at $4 \%$, risce and sugar case are 1 percent. Palm oil industry source are mainly:

$\circ$ Empty fruit bunches (EFB)

- Palm oil mill effluent (POME)

- Mesocarp fiber

- Palm kernel shells

- Palm kernel cake (residue): Mainly lignocellulosic materials

\section{BIOENERGY PROCESS}

Major conversion process of bioenergy:

- Thermal conversion of biomass

- Biological conversion of biomass (organic acid)

- Biological conversion of biomass (methane)

- Biological conversion of biomass (bioplastic)

- Biological conversion of biomass (biocompost)
- Municipal waste (biomass)

Figure 5 shows process that leads to clean and sustainable biomass.

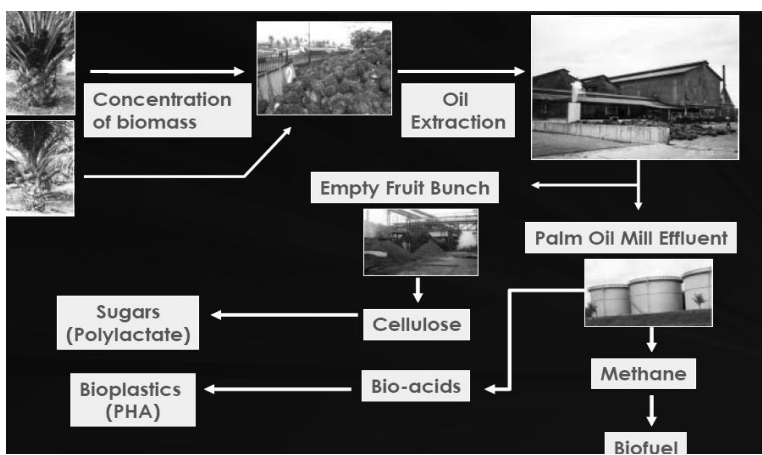

Figure 5: Clean palm oil

Thermal conversion of biomass is mainly use in power/electricity generation

Commercially used in the industries

- Palm oil mills - boilers and steam turbines

- Landfills - methane combustion

It has high demand for energy Low efficiency boiler system - meant for waste disposal in the mill

Biological conversion animal feedstock

Palm-based feedstock:

- Oil palm fronds with added nutrient supplements

- Palm press fiber

- Palm kernel cake

- POME sludge

Sago-based feedstock: Pith residue (starch)

Most of the feedstock from palm-based and sagobased are commercially available

Others:

- Enzyme production by SSF (cellulase, amylase)

- Acetone-butanol-ethanol

1.Municipal solid waste involve Energy (methane) for power/ electricity generation:1st IPP Ayer Hitam Landfill 
2 Chemicals: Organic acids production lactic, acetic, propionic and butyric acids,bioplastics, polylactate Fertilizer, Bio-compost

Malaysia generates in exces of 15000 tons of solid waste per day. The life span of land fill is $5-10$ years, which means that $80 \%$ of the 230 landfil will be closed in 2 years. non biodegradable plastics is widely used in supermarket and the idea of recycling and using waste for energy ring well with this situation.

POME sludge. Domestic sewage has been used to form organic compost having good properties of PH 6-8 suitable for generation and ornamental plants [12]

\subsection{Classification of biomass}

\subsubsection{According to generation types}

Second generation biofuels, are waste derived biomass from agricultural and forestry, fast-growing grasses and trees specially grown as so-called "energy crops".

Third generation biofuels, use green fuels like algae biofuel made from energy and biomass crops that have been designed in such a way that their $s$ tructure or properties conform to the requirements of a particular bioconversion process.

\subsubsection{According to sources types}

North American Electric Reliability Council (NERC) region supply has classified biofuel into the following four types: agricultural residues, energy crops, forestry residues, and urban wood waste and mill residues. A brief description of each type of biomass is provided below [14]:

i. Agricultural residues from the remaining stalks and biomass material left on the ground can be collected and used for energy generation purposes this include residues of wheat straw ii. Energy crops are produced solely or primarily for use as feedstocks in energy generation processes. Energy crops includes hybrid, switch grass grown on idled, or in pasture. The most important agricultural commodity crops being planted in the United States are corn, wheat, and soybeans represent about 70 percent of total cropland harvested. Thus, this is not encouraged to prevent food scarcity.

iii. Forestry residues are composed of logging residues, rough rotten salvageable dead wood, and excess small pole trees.

iv. Urban wood, waste and mill residues are waste woods from manufacturing operations that would otherwise be landfilled. The urban wood waste and mill residue category includes primary mill residues and urban wood such as pallets, construction waste, and demolition debris, which are not otherwise useful.

Biomass for electricity generation is treated in four ways in NEMS:

i. new dedicated biomass or biomass gasification,

ii. existing and new plants that co-fire biomass with coal,

iii. existing plants that combust biomass directly in an open-loop process, and

iv. biomass use in industrial cogeneration applications. Existing biomass plants are accounted for using information such as on-line years, efficiencies, heat rates, and retirement dates, obtained through EIA surveys of the electricity

\subsection{Choice of conventional power system}

Internal Combustion and Diesel Engines:

Steam Turbines:

Stirling Engines: 
Gas Turbines:

\subsection{Biomass Power Generation and Cogeneration Technologies}

Since the palm oil mills have abundant biomass waste resources, their energy systems were designed to be cheap rather than efficient. Most of the existing biomass combustion systems in Malaysia utilize low efficiency low-pressure boilers. The average conversion efficiencies in process steam and electricity generation are $35 \%$ and $3 \%$, respectively. The average overall cogeneration efficiency is $38 \%$. An additional source of energy in palm oil mills is the biogas produced in the anaerobic decomposition (for wastewater treatment purposes) of POME.

Presently, POME-derived biogas is not recovered and used. This $\mathrm{CH} 4-$ rich $(65 \%)$ gas is just allowed to dissipate freely into the atmosphere. Commercially proven technologies are available in the international market for efficient production of power and heat from major biomass resources - bagasse, wood waste, palm oil waste, straw, and rice husk. The state-ofthe-art modern technologies utilize efficient highpressure boilers. Some of these boilers are capable of dual fuel burning, utilizing either liquid (e.g., diesel oil) or gas (e.g., natural gas) fuel as supplementary energy source.Dual fired boilers will be used in palm oil waste-fired boilers to facilitate the use of POMEderived biogas as supplementary fuel.

Local manufacturing capacity of efficient high-pressure steam generators in Malaysia is presently low. Most of the equipment for a biomass-based power generation has to be imported, making the capital cost of a conventional biomass power plant or CHP facility in the country high (typically around US\$ 1,500/kW). Assistance (technical and/or financial) to local steam and power generation equipment manufacturers is critical in motivating them to improve their equipment designs and manufacturing methods $[15,16]$.

Such assistance is provided in the current UNDP-GEF funded Malaysia Industrial Energy Efficiency Improvement Project (MIEEIP). Moreover, with the market potentials of biomassbased power projects and a suitable government policy on power pricing, the local boiler industry could possibly take up the manufacturing of high-pressure biomass boilers, when the market and demand for efficient biomass power technology takes off. Technologies for the effective treatment and handling of POME have been applied in several palm oil mills in Malaysia.

The present systems typically involve the anaerobic decomposition of the organic components of POME and are sufficient to meet the required final effluent BOD limits imposed by the government. As to the biogas $(65 \% \mathrm{CH} 4$, $35 \% \mathrm{CO} 2$ and traces of $\mathrm{H} 2 \mathrm{~S}$ ) produced during POME treatment, there are no government regulations yet requiring palm oil mills to prevent its release to the atmosphere. In case the palm oil mills consider the recovery and energy use of POME-derived biogas, the biogas can be piped from the anaerobic digestion tanks and POME lagoons/ponds and collected in a central storage tank. The biogas can then be treated to remove the corrosive components prior to use. Typical piping system design and installation (including safety and controls) in fuel gas reticulation systems can be applied for this purpose [15].

\subsubsection{Choice of cogeneration alternative energy}

6.3.1.1 Fuel Cells: The principle of the fuel cell was discovered over 150 years ago. NASA has improved the system in their emission free operation for spacecraft. Recent years has also seen improvement in vehicles, stationary and portable applications. As a result of this increased interest, stationary power plants from $200 \mathrm{~W}$ to 2 MW are now commercially available, with 
efficiencies ranging from 30 to $50 \%$ and heat to electricity ratios from $0.5: 1$ to $2: 1$. Hydrogen is the lightest chemical element as demonstrated by the periodic table. Thus, other lighter gas gases exist that can be used as fuel cell, but hydrogen offer greater energy per unit weight compare to other element candidate for alternative energy, and it is completely cyclic as it can be readily combined and decompose. Table 3 shows types of electrolyte source for fuel cell energy. Phosphoric acid fuel cell distribution: Fuel cell can be distributed directly through the following ways [17]:

i. Direct supply to residential and commercial facilities through pipelines Modular cell that can be stack according to power need

ii. Building hydrogen fuel cell power plant in remote location and distribute energy through power grid.

Comparing the efficiency of fuel cell to other source of alternative energy source, fuel cell is the most promising and economical source that guarantee future replacement of fossil fuel. However efficiency maximization of fuel cell power plant remains important issue that needs consideration for its commercialization. As a result the following are important consideration for efficient fuel cell power plant efficiency calculation can be done through the following formula.

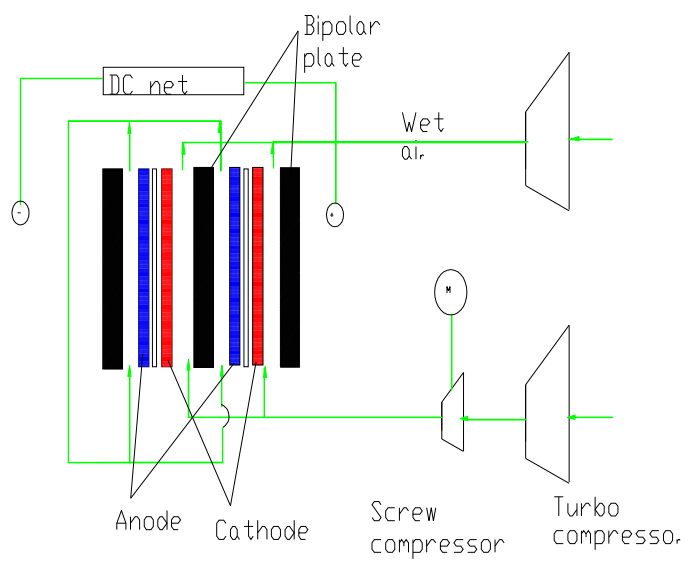

Figure 9: Fuel cell hybrid configuration
6.3.1.2 Solar energy system: Harnessing energy from sun require production, distribution, control and consumer utilization at low cost. Risk work for the system should address the back drop and hybrid system alternative energy system that can be installing as auxiliary for synchronization through automatic control system that activate storage supply whenever supply is approaching the minimum setup limit. Prior to installing solar, it is important to collect, analyze data and information to determined initial condition necessary to start the project and come with acceptable design. Such data should be use for simulation and construction of prototype model of the system that include existing system, central receiver, collectors, power conversion, control system, sunlight storage, solar radiation to supply a solar system to convert sunlight to electricity and distribute through existing channel.

\subsubsection{Hybrid system}

Various types of engine, turbine and fuel cell may be run on a variety of fuels for combined heat and power production. Hybrid system can provide control over power needs, green and sustainable energy that delivers a price that is acceptable and competitive. The power plants can be located where it is needed less high power lines are required, not only reducing costs but assisting health by reducing magnetic fields that people are so worried about, Global warming is addressed $\mathrm{d}$ by direct action by providing power that does not release any emissions or discharges of any kind. The technology associated with the design, manufacture and operation of marine equipment is changing rapidly. The traditional manner in which regulatory requirements for marine electrical power supply systems have developed, based largely on incidents and failures, is no longer acceptable. Figure 10 show a typical hybrid power arrangement for solar hydrogen and conventional power. Figure 11, 12, and 13 can be hybrid to the same system to provide integrated alternative energy power 
Various technologies have been employed towards the use of alternative free energy of the sun since the first discovery in the $18^{\text {th }}$ century. Improvement and development has been made towards making it available for use like existing reigning source of energy. The power plants can be built in small units combined, which allow greater control over the output and maintains full operational output $100 \%$ of the time. The plant produces fewer emissions, the plant can be located close to the areas where the power is required cutting down on the need for expensive high power lines. Excess energy produced can be connected to the grid under power purchase arrangement .

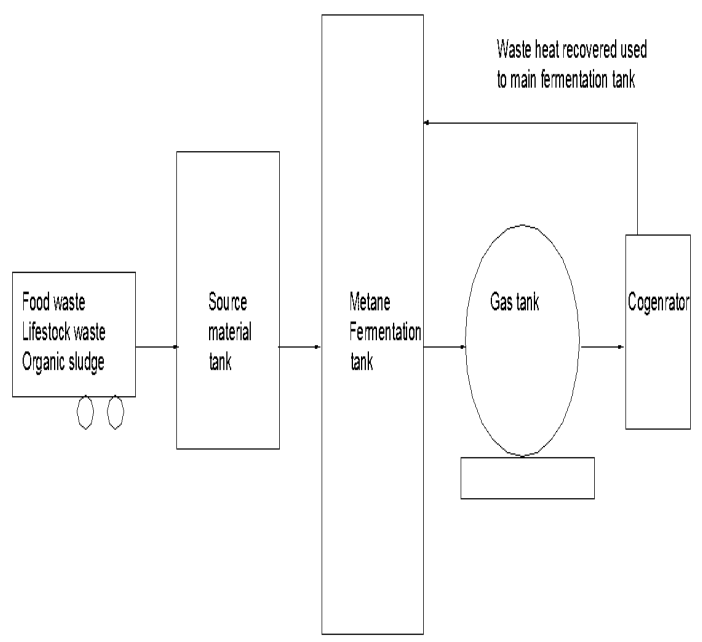

Figure 11: Biogas hybrid

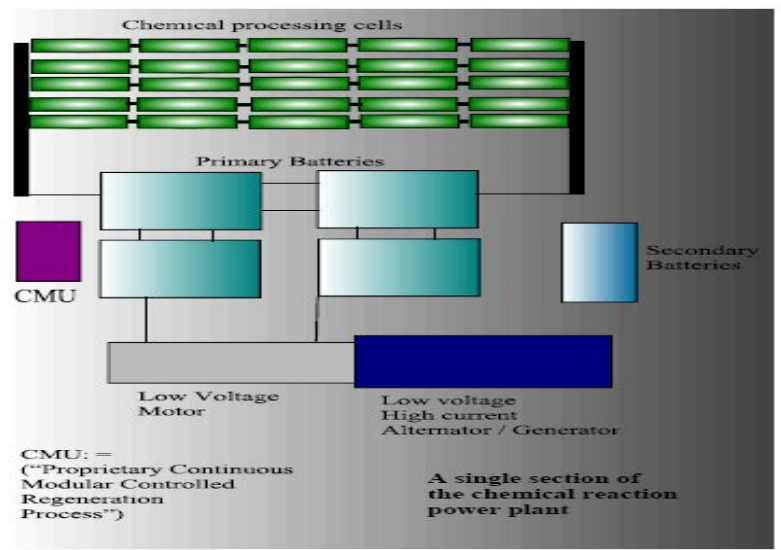

Figure 12: Fuel cell hybrid

The system can be built in independent power configuration and user will be free from supply cut out. In a typical off-grid scenario a large battery bank is required to store energy. Solar hydrogen hybrid energy is stored in the form of hydrogen gas. When it is dark out, instead of drawing energy from a battery bank, hydrogen gas is converted into electricity through a fuel-cell. Likewise, during the day when there is plenty of energy from the sun, water is converted into hydrogen gas through the use of a hydrogen generator. Most electrical power systems are a combination of small units of power group to provide the larger output.

Hybrid system design should begin with problem definition of providing a port with power, follow by refining the design so that each individual units power output could be combined to provide the input for a larger unit and ensure efficient, effect operation, maintenance. The hybrid system should be able to provide more power that can keep the stress and strain of operation to a minimum and reduces the failure of the component parts. The system should be designed with built in redundancy to compensate for failure of a component. The system has advantage of maintenance that can be carries out while keeping the system delivering the full capacity as well as alternation of delivery devices to extend their operational life.

One of the unique features of hybrid system is the sustainable, clean energy system that uses a hydrogen storage system as opposed to traditional battery. Its design construction and functionality are inspired by the theme of regeneration and the philosophy of reuse. High efficiency solar panels works with an electrolyser to generate the hydrogen for fuel cell. The system can universal solar energy for marine application and other energy application as needed in equal capacity to existing fossil power plants. 
Figure 14 shows a typical control system arrangement for the switching.

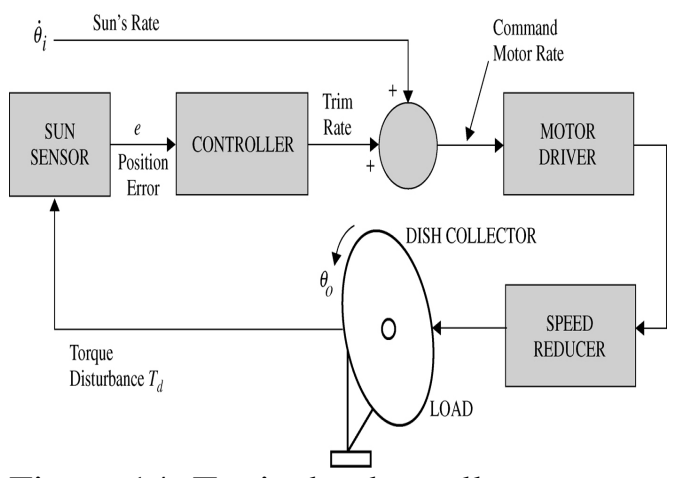

Figure 14: Typical solar collector control system

The hybrid system can provide means to bypass and overcome limitation posed by past work in generating replaceable natural energy of the sun and other renewable energy source that can be designed in hybrid system. Reliable deployment of hybrid system developments of mathematical model follow by prototyping, experimentation and simulation of the system are key to the design and its implementation. The main advantages of hybrid configurations are: Redundancy and modularity, high reliability of hybrid circuitry embedded control system, improve emergency energy switching and transfer, low operating cost through integrated design, low environmental impacts due to nature of the energy source (Sulaiman, 2010).

\section{APPLICATION BIOMASS FUELS IN MALAYSIA}

Malaysia has abundant biomass waste resources coming mainly from its palm oil, wood and agro-industries. A total of about $665 \mathrm{MW}$ capacity can be expected if the estimated overall potential of about 20.8 million tons of biomass residues from these main sources in addition to 31.5 million $\mathrm{m} 3$ of palm oil mill effluents (POME) is used for power generation and cogeneration. In addition, there is a substantial amount of unexploited biomass waste resources in the form of logging wood residues, rice straw, palm tree trunks and other residues. These biomass residues could further supplement future biomass-based power generation in the country if necessary.

The palm oil industry accounts for the largest biomass waste production in Malaysia. Palm oil industry waste (including POME) represents the biggest potential for biomass energy utilization in the country, inasmuch as these are easily available and are presently requiring cost effective means of disposal. Currently, most of these residues are disposed of through incineration and dumping. A small portion is used as fuel for the mills' heat and power requirements in a very inefficient manner.

Domestic: The domestic sector is the main user of biomass fuels, primarily for cooking and space heating. The main user groups are farmers and villagers, but daily wage earners, industrial workers and food vendors in cities all use biomass fuels to some extent. Villagers also use biomass fuels to process agricultural products either for preservation or for conversion into tradable commodities.

Industrial: Many industries in Malaysia use small-scale biomass fuels based on traditional technology for process heat and drying of the final product.. These industries usually purchase the fuel, but some also collect biomass fuels from free supply sources. The industries include: agricultural and food processing (like sugar, rubber and coconut processing, rice parboiling, fish and meat drying and smoking); metal processing and mineral- based activities (e.g. brick making, lime burning, ceramics and pottery, smithing, foundry and jewellery); and forest products and textile industries (e.g. bamboo and cane, distilleries, timber drying, match factories, silk and textiles).

Bio-energy-using industrial and other commercial activities are mainly found in rural areas, but also exist in townships and even metropolitan cities, Also, many households in 
large urban centres use biomass fuels, in particular charcoal. Densified biofuels (briquettes of charcoal fines and loose residues) are becoming more popular in urban centres where different forms of woodfuels have already been accepted as traded commodities. At present, many higher-income rural families, urban households and industrial enterprises are purchasing biomass fuels, especially wood and charcoal, to meet their energy needs.

\section{MODERN APPLICATIONS OF BIOMASS}

Modern bio-energy has developed through adoption of technologies like cogeneration (generation of heat and power in wood and agrobased industries) and dendrothermal power plants (generation of electricity by burning woody biomass). Cogeneration is gaining increasing acceptance. Efficient, mature and proven biomass-based energy conversion technologies are available. Cogeneration of heat and power from residues in forest-based and agroindustries is being increasingly promoted in Malaysia and ASEAN countries by the private sector, mostly for own use. Utility companies in Western countries already supply electricity and heat from biomass to national grids and local communities

Many palm oil mills utilized oil palm Residues for production of electrical energy \& heat in co-generation for their own use. In 1990's EC-ASEAN COGEN built 5 Full-Scale Demonstration Projects (FSDP) in Malaysia utilizing wastes in wood industries using cogeneration systems. In 1980's national electrical utility company developed many minihydro plants supplying electricity to remote communities

Third Outline Perspective Plan (OPP3) 2001-2010 and the 8th Malaysia Plan 2006-2010 forcasted That Malaysia may net oil importer by 2008 _ Air pollution reduction in transportation \&industrial sectors using natural gas and clean coal technology Sustainable energy development through secure cost-effective supply Efficient utilization \& minimization of environmental effects of energy Introduction of renewable energy as the fifth fuel Promotion of energy efficiency

In 1999, renewable energy added as fifth "fuel" in addition to oil, coal, gas \& hydropower with target for renewable energy $5 \%$ by $2005 \&$ $10 \%$ by 2010 Fuel mix in 2010 Malaysia currently target $40 \%$ coal, $10 \%$ hydropower and $10 \%$ renewable energy Biomass resources utilized for electricity generation and connection to the national grid. The total generating capacity of oil palm based biomass for own use in 2002 is 150 MW with Total capacity oil palm biomass: 2400 MW $[1,18]$.

The Malaysia Small Renewable Power program attracted. He following is the breakdown of 115 applications for biomass out of which 65 equivalent of $368.9 \mathrm{MW}$ are approved.

Table 2 : Sources of biomass in Malaysia

\begin{tabular}{|l|l|l|}
\hline & & \\
\hline $\begin{array}{l}\text { oil palm } \\
\text { biomass }\end{array}$ & 27 & $214.7 \mathrm{MW}$ \\
\hline $\begin{array}{l}\text { rice husks } \\
\text { projects }\end{array}$ & 2 & $12 \mathrm{MW}$ \\
\hline $\begin{array}{l}\text { wood } \\
\text { residue } \\
\text { project }\end{array}$ & 1 & $5 \mathrm{MW}$ \\
\hline $\begin{array}{l}\text { municipal } \\
\text { solid wastes } \\
\text { project }\end{array}$ & 1 & $19.2 \mathrm{MW}$ \\
\hline $\begin{array}{l}\text { mixed } \\
\text { biomass } \\
\text { projects }\end{array}$ & 3 & $10.2 \mathrm{MW}$ \\
\hline $\begin{array}{l}\text { landfill gas } \\
\text { (biogas) } \\
\text { projects }\end{array}$ & 5 & $101.6 \mathrm{MW}$ \\
\hline $\begin{array}{l}\text { mini- } \\
\text { hydroelectric } \\
\text { projects }\end{array}$ & 26 & \\
\hline
\end{tabular}

Source: Energy commission, 2006 
Other best practice includes:

1. UNDP \& Malaysian Government implemented Biomass-based Power Generation and Cogeneration in the Malaysian Palm Oil Industry (BIOGEN), whose main objective include Reduction in the growth rate of green-house gas emissions from fossil fuel by utilizing excess oil palm biomass residues through development and exploitation of the energy potentials of other biomass wastes.

- The elements of BIOGEN include:

- development of the grid connected biomass fuelled small power systems,

- disseminating awareness information in palm oil Industry

- capacity building and technical assistance in policy formulation.

- Facilititation of financial assistance through favourable bank loans and tax exemption.

- establishment of real live demonstration plants and development of biomass energy technology

Target of Phase 1 (2 years) of BIOGEN 15\% of palm oil mills (50 palm oil mills) to implement biomass power generation \&cogeneration. Target of phase 2 (year 5), green house gas emissions from power generation reduced by. $3.8 \%$ _ Up to 2004 there was only 1 major BIOGEN project 14 MW oil palm residues mitigate 40,000 to 50,000 tonnes $\mathrm{CO} 2$

2. Palm Oil Research Institute of Malaysia (PORIM) now Malaysian Palm Oil Board (MPOB) has been involved in biodiesel program for along time. In the early 80's, PORIM developed biodiesel using transesterification technology that was used $100 \%$ on special engines from Germany. Lack of interest from transportation \& automobile industry
Currently there is no policy from government. On High price of palm oil \& low price of oil. Recent revival of interest due to increasing oil prices and falling palm oil prices.

3 German-based train operator Prignitzer. Eisenbahn (PE) Arriva tested 50 tonnes of Malaysia's biodiesel \& ordering additional 100 tonnes of the fuel

4. Legislation to require oil companies to sell. biodiesel at their petrol stations Three biodiesel plants with capacity of 60,000 tonne/yr. are planned for 2006. Each Total capacity by next year is 180,000 . tonne/yr biodiesel mainly for export only. _ Raw material is refined, bleached and deoderised (RBD) palm oil Biodiesel composition: $5 \%$ processed palm. oil blended with $95 \%$ petroleum diesel for diesel engine vehicles and industrial and power generation

5. Felda together with Kyushu institute of technology and sumitoto heavy industry project utilized biological conversion that involve methane generated from POME anerobic treatment, 5000 cubic metr methane tank, , POME holdiong tank, settling tank, gas scruber, gas storagetank and gaversion to electricity use gas turbine as prime mover. Figure 6 shows typical biomass production process.

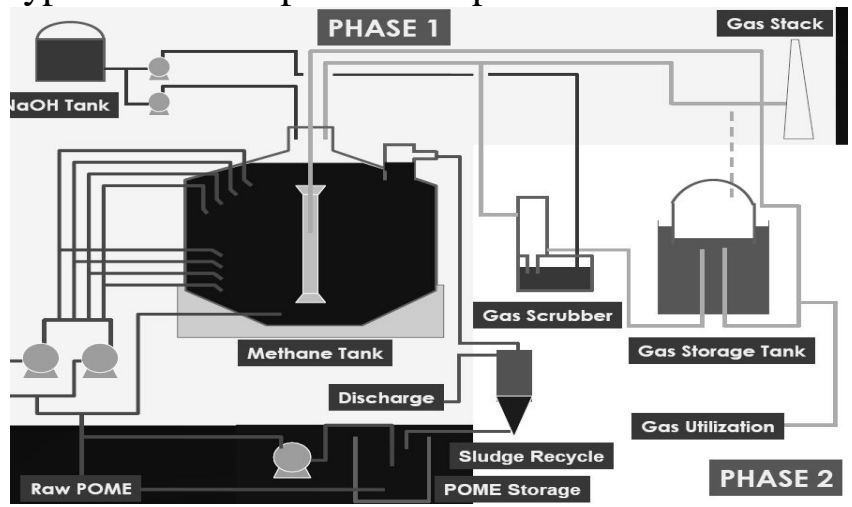

Figure 6: Biomass production process

Another felda project utilized bioplastic and organic acid (acelic propianic and bulyric acids from POME) that fermenti organic acid into poly-hyroxyalkanoates. The process use excess 
energy from biogas plant and subsequent distillation of organic acid.

6. TSH bioenergy project is another case in Malsyia, located in Sabah, with generation capacity of $14 \mathrm{MW}$, the system use palm $\mathrm{m}$ oil as fuel source (Figure 8).

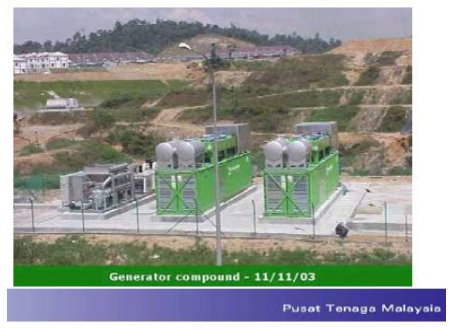

Figure 7: THS bioenergy plant

7. Janal landfill sdn located at air hitam , Selangor, also lunched biomass project with 2MW capacity, fuel by biogas captured from landfill (Figure 9)

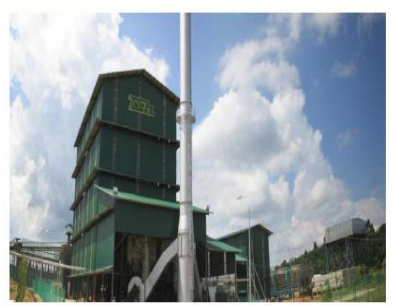

Figure 9: Janal Landfilbiogas power plant

\section{BIOMASS DEVELOPMENTAL TREND SPILLAGE TO SHIPPING}

Just like tanker revolution influence on ship type, demand for biomass will bring capacity, bio - material change from source to production area to the point of use. Technological, environmental change will also require ships of different configuration, size and tank coating type as well as impact on the tonne mile demand. Recently biofuel is driving a new technology worldwide; the use of biofuels for cars and public vehicles has grown significantly. Effect on shipping is likely to be followed by shipping of large scale growth on exports and seaborne trade of biomass product from key exporting regions in order to balance supply and demand. With excess capacity waiting for source material it seems inevitable that shipping demand will increase. Figure 10 shows a typical cogeneration for marine system.

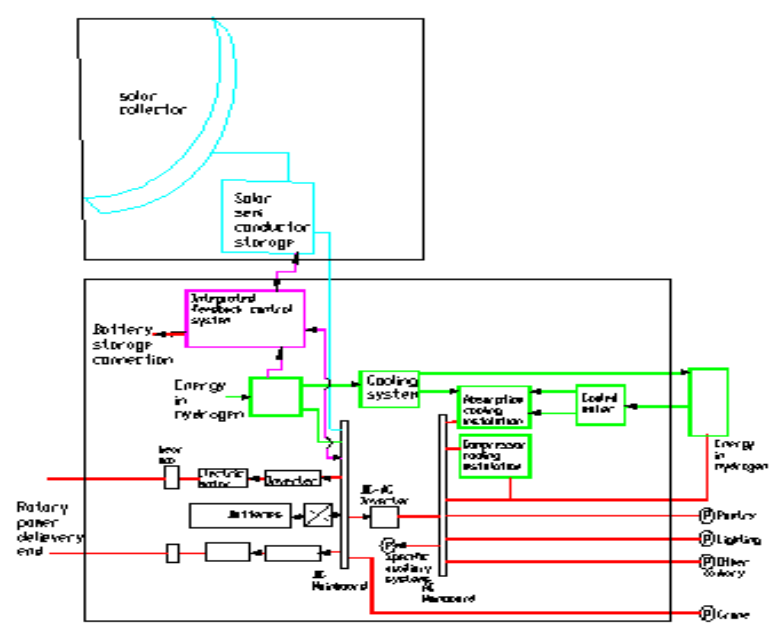

Figure 10: Cogeneration for marine ship system

In many parts of the world, environmental concerns are the leading political driver for biofuels. This driving force evolved regulation like Kyoto protocoal, Marpol Annex VI and other environmental regulation. The tonne mile demand for future tankers will be greatly affected by national, regional, global policy and political decision making. There is a greater flexibility in the sourcing of biofuels than there is in hydrocarbon energy sources and this may be attractive to particular governments. Once the regulatory framework is clear, economics will determine how the regulations will best be met and seaborne trade will be at the centre of the outcome [20, 21, 22].

\section{SUSTAINABILITY REQUIREMENT FOR BIOMASSS}

\subsection{Environment}

If the supply source is properly managed, woodfuel can contribute positively to both the local and the global environment. Degradation of watershed and catchment areas occurs only when 
woodfuel is extracted in an unsustainable manner from environment

Biomass resources, particularly residues from forests, wood processing, agricultural crops and agro-processing, are under-utilised in Malaysia and ASEAN countries. These resources are renewable, environmentally friendly in energy production, and sustainable in terms of supply. Some of these residues are already used as raw materials for other products (such as particle board and fibreboard), as fodder and fertilizer, or as household and industrial fuels. However, large portions are still unused and represent potential sources of energy. Energy generation technologies specifically designed to use biomass residues are available and are becoming more and more economical. Countries have yet to make optimum use of the additional power generation potential from their biomass residue resources, which could help them to partially overcome the long-term problem of energy supply. However, in order to make the most of biomass energy, various aspects must be taken into account $[16,17]$ :

\subsection{Financial}

There are several factors limiting the potential for large-scale fast-growing fuelwood plantations on a commercial scale: international petroleum fuel prices, remaining subsidies on commercial fuels, large initial investment requirements for woodfuel plantations, long gestation period between planting and harvesting, and conversion and transportation costs. This implies that the development of woodfuel should focus on the by-products of agroforestry and on the use of wood and biomass residues from relevant processing industries at their source..

Biomass fuels are mostly used in the household sector, primarily by the rural and urban poor and middle-class people in small towns. These people usually end up paying more for their household energy than their counterparts in larger urban centres. Cost-benefit analyses should incorporate avoided costs.
- The low income level of the majority of rural woodfuel users cannot support high investments in modern biomass-based energy generation. Governments should come in with financial schemes.

\subsection{Technological}

Biomass has a lower calorific value than fossil fuels. Densification (briquetting) of biomass residues increases accessibility but involves a cost, which may be out of reach of those present users who get their biomass fuels free. Detailed study of the local fuel market and careful selection of technology should precede major investments in biomass energy development.

Prevailing practices of technology transfer do not sufficiently take into account the local conditions under which imported technology has to be operated and managed, the training required for its use, maintenance requirements and capabilities, and backstopping arrangements. Promoters need to consider both hardware and software aspects of technology transfer. Research and development for biomass production and use on a commercial basis has not yet received adequate attention in the region.

\subsection{Community participation}

Numerous actors play specific roles in the supply and distribution of traded biomass fuels from their sources to final users (e.g. collectors or gatherers, transporters, middlemen, wholesalers and retailers). Woodfuel collection for self-use and for the market can be an important occupation in rural areas. For the better-off it may be part-time off-season work, but for the poor it can very well be a full-time occupation for livelihood. And for yet others it may provide an opportunity for self-employment in woodfuelrelated business to earn cash income and supplement household income. Most fuelwood gatherers live in villages close to the forests. They 
may be poor with very small land holdings, or landless labourers. Estimated employment of woodfuel on the basis of person-days involved in production of one terajoule (TJ) of energy, compared to other commercial fuel alternatives, shows just 10 person-days per TJ for kerosene, compared to 200 to 350 person days for charcoal, depending upon productivity of site, efficiency of producers and the distance to the market.

Also, woodfuel is a carbon- neutral energy source (that is, the $\mathrm{CO} 2$ released by its burning is matched by the amount used up in its production), provided the rate of harvest of the wood is equal to the rate of re-growth, so it need not contribute to the greenhouse effect. With present improvements in wood combustion technologies, other emissions like carbon monoxide (CO), polycyclo-aromoatic-hydrocarbons (PACs), nitrous oxides (NOx) and particulate matter can also be significantly reduced.

Considering the important contribution from non-forest production sources, most areas sustainable production of wood for energy can be viable. The present supply-demand imbalances may not be as serious as has been projected for most countries. It is also observed that, except in some highly populated forest deficit areas, the use of woodfuel by a majority of rural households is not the root cause of deforestation. In the present context of warnings against deforestation and growing concernsnabout biodiversity and environmental conservation, the role of government-raised plantations as newly emerging additional sources of woodfuel becomes more prominent as far as traded woodfuel is concerned.

\section{Institutional engagement}

- Governments' policies relating to biomass energy development and the role of the private sector are not yet clearly defined.

\section{ADVANTAGES \& CONSTRAINTS}

\subsection{Advantages}

1. Economy: Modern applications in both industrialized countries and in South-East Asia have demonstrated that biomass energy has potential for larger-scale industrial applications. For fuel-importing countries, the use of local biomass can save substantial amounts of foreign exchange. The value of agricultural waste fuels currently being used in Malaysia economies is equivalent to an estimated US\$ 7 billion annually.

2. Environment: The sustainable use of biomass energy sources helps to manage the local environment. When wood and other biomass are properly valued by local populations as an important resource base, they are more likely to be protected. Sustainable use of biomass is also beneficial for the global climate, because it is carbon-neutral, and greenhouse effect mitigation. This is the main reason why many industrialized countries have embarked upon policies for increasing the share of biomass in national energy consumption. The same policy is currently being announced in Malaysia.

3. Rural income: The use of wood and some other forms of biomass energy generates at least 20 times more local employment within the national economy. A large amount of unskilled labour is engaged in growing, harvesting, processing, transporting and trading the fuels, which generates off-farm income for rural populations, either regularly or off-season. Policy makers in the Malaysia are increasingly coming to recognise the employment benefits for their own countries.

4. Social: In times of hardship, or when harvests are inadequate for subsistence, 
the opportunity to generate income in woodfuel business provides a safety-net for the people affected $[18,19]$.

5. Efficiency: The application of biomass energy in modern technologies allows for increased energy efficiency by combined heat and power generation (cogeneration). Applications of cogeneration in decentralised systems based on locally available fuel resources help to further reduce losses in the transmission and distribution of power. Energy mix: Incorporation of biomass fuels in national energy supply policy improves the energy mix by increasing the diversity of energy sources. This helps to reduce vulnerability to market fluctuations and can improve stabilization of prices [18, 19].

]

\subsection{Constraints}

Planned demonstration programs in Malaysia that aims to showcase technologies on power generation using biomass and/or biomass-derived energy forms have to contend with several barriers Major barrier for development and implementation of biomass are: issue of concern includes [22]:

1. Lack of awareness: It is sometimes assumed that biomass energy is a traditional commodity which will phase out in the near future. Some people even believe that woodfuel collection poses a major threat to tropical rainforests. Misconceptions such as these hamper the development of sound energy policies. There is lack of Information Services to Promote Biomass Energy Development and Applications. There is a general misconception that biomass-based grid connected power generation is an unproven technology and business venture, and that the use of biomass fuels goes against the industrialization goals of the country. There is the common notion that the industry lacks the technical capability and experience in this particular field of biomass energy technology. The potential biomass energy project developers do not know where to obtain sufficient information as well as competent advise in matters related to the choice of technology, legal issues, preparation of agreements/contracts, financing, and etc. Since biomass-based power generation and sales is new to, and not within, the core business of the palm oil industry, the palm oil mills and potential investors usually do not have enough information related to the implementation of such kind of projects.

2. Lack of accessible and favorable financing schemes Financial, institutional and legal issues have to be resolved to make the best use of available technologies. Due to lack of support policies and information; it is difficult to obtain financing for biomass-based power generation projects in Malaysia. This is further aggravated by the fact that financial/banking institutions in the country are not familiar with the financing of such business ventures.

3. Lack of policies on biomass energy technology development and applications: Currently, there is no formal government policy concerning the development and utilization of biomass energy. Thu, there is an existing policy regarding IPPs selling power to TNB, there is no basic regulatory framework for biomass power projects to sell excess power to the utility grid. The Ministry of Energy, Communications and Multimedia has set up a Special Committee on Renewable Energy (SCORE) that will be responsible 
for policy and institutional arrangements to promote the development of renewable energy resources in the country. SCORE includes TNB Distribution, EPU, JBEG and the Ministry of Finance. It is important for biomass projects to use SCORE in developing an appropriate regulatory framework.

\subsection{Uncertainty}

Major uncertainties are described below:

1. Uncertainty financial viability: Due to the perceived high risks, these institutions are cautious in providing financial assistance for such kind of projects. Only a few of the existing technology financing schemes in the country include renewable energy in their portfolios. Base on past experience, such schemes usually require a long application and approval process. Biomass-based power generation in the palm oil industry has long been practiced but power sales to the grid have not been done due to poor economics arising mainly from the inability to sell to the grid and to sell at favorable rates. It is important to have a central system for relevant stakeholders (including Energy Service Industries (ESIs)), aside from the pertinent government support policies and regulations in order for biomassbased power generation to be attractive business venture. Negotiations have been ongoing amongst concerned stakeholders to arrive at a final level playing field.

2. Lack of data, successful technology, and models to demonstrate the viability of biomass-based grid connected power generation systems: The experience so far in Malaysia is limited to the existing inefficient biomass-fired systems in the palm oil and wood industries. There has been no successful experience utilizing efficient biomass-based power generation systems that sell excess electricity to the grid or to other electricity user. Generating and selling electricity is beyond the scope of the palm oil mills' core business and is not within their area of competence. Moreover, while some of the palm oil millers are interested in the technology, they are reluctant to take the risks of being the first to implement this commonly regarded "new" technology. Also data are still inadequate or unavailable for biomass energy planning and for developing specific energy policies for supply and demand. Technologies for biomass combustion which are at present widely used in Malaysia need to be improved towards best practice.

3. Uncertainties of Biomass Fuel Supply: Overall, the potential for biomass-based power generation looks good. There is presently the general perception that with the overall amount of palm oil industry waste resources, it would be possible to achieve the target \%share (i.e., 5\%) of renewable energy resources in the national power generation mix by year 2005 . The reliability of continuous supply of biomass waste (particularly solid waste) fuels from the nearby mills is critical to the full operation of the power generation facility in each demo site. The national utility (TNB), which is expected to purchase the electricity generated perceives that the supply of would be unreliable due to Uncertainty in the actual volume and quality of the palm oil milling operations and absence of standard contract procedures concerning the supply and pricing. It could also be costly to transport biomass waste residues from various palm oil mills to the biomassbased power generation facility. The price of biomass residues might also increase in 
the future, as other value added uses and opportunities are identified.

4. Uncertainties of Meeting Minimum Energy Off Take: Solid-fuel fired power plants would usually be base loaded. These would generally have an

5. availability factor of $90 \%$. Spare capacity would normally be provided to ensure meeting minimum energy off-take (MEOT) requirements as stipulated in purchase power agreements (PPA), and to allow for maintenance and force outages. Considering the uncertainty in the longterm supply of the EFBs from other mills, the demo sites may not be able to operate at levels that would meet MEOT requirements of TNB. The seasonal availability of biomass residues is a major risk for grid-connected biomass-based IPP, operating under a PPA with TNB.

6. Uncertainties in the Implementation of Biomass-based Energy Technology: There is a general apprehension that should palm oil mills be allowed to sell electricity to the grid, the power supply from these sites is unreliable judging from the way they presently operate their facilities. The common knowledge that the mills deliberately operate their facilities inefficiently in order to get rid of their biomass waste gives the impression that the mills are not up to the stringent reliability and efficiency requirements in the operation of grid-connected power plants. Like in the wood and agro-based industries, which also use biomass waste for energy purposes, biomass combustion in the palm oil industry needs to be improved towards best practice. Power sales to the grid require more efficient power and steam generation equipment, reliable interconnection safety and synchronization devices, as well as more sophisticated power project development skills to deal with broader technical and contractual issues. Moreover, there are limited manpower skills in the palm oil industry to operate and maintain the modern efficient biomass fuel-fired power equipment. Although the palm oil mill operators have good knowledge of power generation at the $500 \mathrm{~kW}$ levels, grid connection knowledge and expertise are lacking.

7. Uncertainty of Power Purchase by TNB Distribution: The realization of the demo schemes is very much dependent on the purchase of the generated electricity by TNB Distribution. The issue here is the return on investment and the ease. The above barriers continue to hinder the replication of any biomass-based power generation initiatives that palm oil industry may be interested to invest in. with which the grid connection will be made between TNB Distribution and the host companies. Presently, there is no framework to accommodate this business relationship. TNB Distribution will most likely exercise its right to insist on due diligence on host company's proposal on the interconnection. This is to at least satisfy TNB Distribution that the link between power plant and its distribution system will be adequately and suitably protected from frequency and voltage variations, etc.

Measure and mitigation option are sumarrised in Table 3 Main supporting measure by Malaysia government can be summarized into the following:

- Local authority facilitation

- Lower tarrif

- Technical and financial consulting

- Application facilitation

- Soft loan facilitation 
Table 3: Summary of barriers and ways to overcome them

\begin{tabular}{|c|c|c|}
\hline Components & Barriers & Possible solution \\
\hline $\begin{array}{l}\text { Technical } \\
\text { component }\end{array}$ & $\begin{array}{l}\text { - lack of successful } \\
\text { references } \\
\text { - seen as complicated } \\
\text { to operate } \\
\text { - the quality of biomass } \\
\text { as a fuel is not } \\
\text { homogeneous }\end{array}$ & $\begin{array}{l}\text { - implementation of demonstration projects } \\
\text { - suppliers to simplify operation; training of } \\
\text { operators } \\
\text { - adequate testing of samples }\end{array}$ \\
\hline $\begin{array}{l}\text { Human } \\
\text { component }\end{array}$ & $\begin{array}{l}\text { - energy not a core } \\
\text { business of potential } \\
\text { users } \\
\text { - risk of being the first } \\
\text { to fail }\end{array}$ & $\begin{array}{l}\text { - create awareness of benefits and opportunities } \\
\text { - references in similar environment; } \\
\text { demonstration projects }\end{array}$ \\
\hline $\begin{array}{l}\text { Information } \\
\text { component }\end{array}$ & $\begin{array}{l}\text { - lack of institutions } \\
\text { giving information } \\
\text { and advice } \\
\text { - lack of awareness } \\
\text { among users on } \\
\text { government rules and } \\
\text { incentives } \\
\text { - not enough technical } \\
\text { and economic } \\
\text { information to make a } \\
\text { decision }\end{array}$ & $\begin{array}{l}\text { - strengthening of relevant networks } \\
\text { - information drive } \\
\text { - availability of funds or services to conduct } \\
\text { feasibility studies }\end{array}$ \\
\hline $\begin{array}{l}\text { Organisation } \\
\text { al component }\end{array}$ & $\begin{array}{l}\text { structure of the } \\
\text { industry } \\
\text { - size of mills } \\
\text { - transportation } \\
\text { problems } \\
\text { - seasonality } \\
\text { uncertainty of } \\
\text { biomass fuel supply } \\
\text { - policy, legal and } \\
\text { government issues } \\
\text { - financial barriers }\end{array}$ & $\begin{array}{l}\text { - thorough investigation of these aspects in the } \\
\text { feasibility of projects } \\
\text { - initiatives to boost yield and productivity } \\
\text { - government incentives/ support measures? } \\
\text { - innovative financial strategies; government } \\
\text { incentives? }\end{array}$ \\
\hline
\end{tabular}

\section{RISKS AND SUSTAINABILITY}

\subsection{RISKS AND STEPS TAKEN TO MINIMIZE THEM}

For future projects, the potential risk will have to be carefully evaluated and mitigated by a relevant government policy. Among main issue that hinder development of biomass is lack of support policies regarding the development and use of biomass energy and the pricing of biomass generated electricity sold to the grid. The potential conversion of land into plantations and to use monoculture techniques carries the risk that biodiversity may be lost due to the conversion of forest into farmland and that soil may be lost due to erosion. The oil palm plantation industry in Malaysia is at a mature stage where regulations have been established to mitigate its negative environmental impact. Soil erosion is not a significant problem due to well developed terracing techniques and the fact that oil palms are mainly grown on level land. The 8th Malaysia Plan, risk aversion strategy focus on the following:

1. Uncertainties of Biomass Source Fuel Supply: there is threat of oil palm plantations conversion to real estate developments in Peninsular Malaysia. The supply of biomass fuel will also be sustained by the availability of biomass residues resulting from the annual replanting of palm oil trees, which typically involve about 100,000 hectares of plantation land. The availability of POME-biogas will also ensure the availability of supplementary fuel for power generation.

2. Uncertainties of meeting Minimum Energy Off Take requirement: With the availability of standard long-term biomass supply agreements and its implementation, biomass-based power grid connected power plants facilities are supposed to operate reliably to meet requirements.

3. Uncertainties of Power Purchase by TNB: Malaysia currently plan for open electricity market which might discourage TNB power purchase. In case of an open market, TNB Distribution is still expected to honor its PPA arrangements with IPPs. The Ministry of Energy, Communications and Multimedia's will be responsible for ensuring the promotion of grid-connected power generation from renewable energy resources. The Ministry currently pledge special attention will be given for power purchase from biomass power plants.

4. Uncertainties in the Malaysian Financial Sector: Malaysia is currently withstanding the impact of the US slowdown. The 
financial institution sector is wary about their financing deals with industries. With the current political will, , enforcement of the relevant policies concerning the use of biomass energy, the implementation of attractive RE electricity tariffs, granting of financial incentives, issuance of PPAs to biomass-based power generators, financial risk can be mitigated $[17,20]$.

5. Operating Risks: Currently there are limited manpower skills in the palm oil industry to operate and maintain the modern efficient biomass fuel-fired power equipment. This can however be easily addressed by the capacity building, training to be provided by the power and steam generation equipment suppliers.

\subsection{SUSTAINABILITY}

Sustainability will require addressing issue related to policies, regulations (including tax, incentives etc.), financing and numerous stakeholders and institutional roles. Biomassbased power generation remain a reliable and cost-effective technology in the international market. This could be further sustained by building capacity to provide technical information and advisory services to potential biomass-based power project developers and investors. Sustainable demand for and supply of biomass power systems could also be achieved through disseminating information, supporting the demonstration schemes and carrying out barrier removal activities to ensure successful implementation and subsequent replications.

The Malaysia fifth fuel plan has sustainable potential by helping $t \mathrm{o}$ formulate and enforce policies and regulations regarding the use biomass energy for power generation in Malaysia. It will facilitate the review and improvement of electricity pricing policies, particularly concerning biomass-generated electricity or RE electricity and facilitate policy dialogue for smooth adoption and implementation of the pricing policy and incentives, which will ensure the commercial viability of future biomass-based power projects.

To sustain the momentum that will be generated by the initial project activities, it is imperative to set up a financing mechanism for RE-based power projects by providing financial assistance for the replication of the technologies. It is also important to train the financial institutions in financing biomass power projects to ensure continuity in the financing of future projects, as well as promote investment opportunities for potential investors in Malaysia.

The government policies and regulations that will be put in place and implemented through this project will influence growing interest in biomass-related industries (e.g., wood, and agriculture) in developing and implementing biomass-based power generation in other to ensure the institutional sustainability of this project.

\section{STAKEHOLDER of BIOMASS ENRGY IN M ALAYSAI}

The interests of primary stakeholders in the project are described below:

1. Ministry of Energy, Communications and Multimedia (MECM) MECM is the cocoordinating and implementing agency for energy policies in Malaysia who is responsible for inter-ministerial coordination in matters concerning the energy sector. It chairs the Electricity Supply Planning Committee formed in 1997 to monitor and review the supply and demand situation regularly. The MECM is involved in the approval of electricity tariffs and issues licenses to 
supply electricity. It is also responsible for the development and implementation of renewable energy and energy efficiency programs. Department of Electricity and Gas Supply (JBEG) JBEG is a department under the control of MECM. This department develops legal and regulatory frameworks, advises the Ministry on policy, tariff and other matters. JBEG is

2. Malaysian Energy Centre (PTM) PTM is non-profit company and administered by MECM. The establishment of PTM is to fulfill the need for national energy research center that will co-ordinate various activities, specifically energy planning and research, EE, technological research and R\&D demonstration. PTM will eventually become the one stop focal point for linkages with the universities, research institutions, industries and various national and international organizations on energy matters.

3. Economic Planning Unit (EPU): EPU formulates privatization policies and evaluates and selects and approves Independent Power Producers (IPPs) responsible for the formulation of energy strategies and policies including national energy planning and policy development in renewable energy. EPU is interested in the palm oil biomass project to clarify the potential for integration of renewable energy into the Malaysian electricity supply system. There are a number of RE projects being supported by the Electricity Supply Industry Trust Account (MESITA), which is managed by the MECM.

4. Ministry of Science, Technology and the Environment (MOSTE) MOSTE is responsible to promote research and development activities, which can be commercialized, and support environmental conservation and sustainable development such as renewable energy project utilization.

5. Ministry of Finance (MOF) The MOF is responsible in determining the annual budget for all the government departments and Ministries. It is the Ministry to finally approve matters related to investment incentives and tax exemptions. Ministry of Primary Industries (MPI): MPI is responsible to establish and enhance Malaysia's competitive advantage in a global market for selected export commodities as well as their value added products. It promotes specific commodities considered to be economically and socially strategic to national development. The palm oil industry is under this Ministry. The ministry is in supportive of cogeneration and provides guidelines for interconnection between the biomass power plant and Tenaga Nasional.

6. Malaysian Palm Oil Board (MPOB) MPOB is department merged between the former Palm Oil Research Institute of Malaysia and Palm Oil Research Licensing Authority) under the control of MPI. MPOB carries out R\&D activities and approval of processing plant on palm oil industry. It is the focal point for the palm oil industries $\mathrm{R} \& \mathrm{D}$ activities and is strongly supported by the industries. MPOB has commissioned an efficient biomass boiler system at its palm oil mill.

7. Malaysia Palm Oil Millers Association (POMA): The Association comprises about 60 members, mainly from the private millers. POMA has three regional offices covering northern, central and southern regions of Malaysia. The main responsibilities of POMA is to coordinate the activities of its member companies and hold dialogues with government 
agencies such as the Department of Environment, MPOB, MPI and MoF.

8. Malaysian Palm Oil Association (MPOA): MPOA's mission is to ensure the longterm profitability and growth of the Malaysian palm oil industry and other plantation crops. Its role includes shaping R\&D policies and priorities and dissemination of industry-relevant information to members. Among its priority issues are environmental concerns.

9. Tenaga Nasional Berhad (TNB): TNB is the national power company own by the government. It has a few subsidiaries namely TNB Distribution, TNB Generation, TNB Engineering and Consultancy, TSPL and TNB Research. TSPL is the main subsidiary responsible for the development of renewable energy projects. TNB purchase the excess power from the small biomass power plant at a price to be negotiated between buyer and seller.

10. SIRIM Berhad (SIRIM): SIRIM Berhad is the national organization on industrial R\&D activities and quality standards. It has been active in promoting the renewable energy and energy efficiency projects. The energy projects are handled by the Environmental and Energy Technology Centre, which carried out the preliminary feasibility study on grid connected power generation using biomass. The Centre has managing the national and international project such as ASEANEC COGEN Programme me. The program supports projects involving the installation of cogeneration plants from various type of biomass was and the generation capacity between $500 \mathrm{~kW}$ to 2000 kW. Universities UKM, USM, UTM and UPM have been active in promoting $\mathrm{RE}$ and EE activities. The universities offer courses and carry out research in RE and EE.
11. The Government, through the IRPA (Intensified Research in Priority Areas) funding mechanism, funds most of the research grants. The universities also offer consultancy services to industries and work closely with government agencies.

\section{FUTURE OF BIOMASS IN MALAYSIA}

Limited opportunity exists for exchange of information and sharing of experiences with regard to the use of modern biomass energy technologies amongst implementing organisations within Malaysia It is important to facilitate transfer of knowhow through development and institutionalization of a system for facilitating information sharing and technology transfer within the region. Bases with regard to prices, competing uses, cost of biomass energy in relation to alternatives, energy market, size, and supply sources.

- Data bases should be accessible to agencies willing to finance, implement, monitor or use biomass energy. Exchange of information between countries in the region can be promoted by networking and through collaboration with regional and international agencies. It is important to integrate wood and biomass energy information into energy data bases; identify data gaps which limit the integration of wood/biomass energy considerations into long-term development programmes. Identify data collection activities which countries need to undertake to fill these data gaps; Data on supply and demand of biomass energy should be collected systematically and periodically. The data should be used by planning units as a basis for energy policies and incentive [19, 21].

- No dedicated system exists for information flow on research and development in biomass energy. This needs to be established and regularly upgraded. Legislation

- Most policies and legislation today are not conducive to biomass energy development, e.g. 
sectoral policies and legislation governing private trees in non-forest lands, including planting, harvesting, utilisation, transport of tree and wood products, tree and land ownership and tenure systems.

- Curent policies use subsidies to promote the use of commercial fuels, instead of developing the sources and supply of biomass energy, which could contribute positively to the balance of trade. Assist in the development of sustainable energy policies. Fiscal and pricing policies should be reviewed, so as to remove discrimination in favour of certain fuel sources. Biomass energy should be allowed a "level playing field"

in competition with other renewables and fossil fuels.

- Lack of awareness about use of biomass fuel being the root cause of deforestation and environmental degradation do not provide a conducive atmosphere for bio-energy development. Appropriate legislation which regulates only indiscriminate biomass use needs to be promoted.

- Prevailing arrangements do not encourage private-sector participation in the development of biomass resources in forest and nonforest areas. Utilisation of biomass for commercial energy production and marketing requires legislative provisions and incentives. Wherever feasible, countries should encourage, through legal and financial provisions, the plantation of fastgrowing multipurpose trees, if not as singlepurpose plantations then as part of larger, multiple-use production systems.

\section{CONCLUSION}

Geographical location provides favorable conditions for growing biomass, which can strengthen their self-reliance in terms of energy. Clear and consistent policies are needed to make the most of this. Modern power generation from biomass sources should be further developed. energy sector, 8MP focuses on renewable energy \& energy efficiency as the fifth fuel by expanding four-fuel diversification policy introduced in
1979. Fiscal incentives, policy instruments renewable energy strategies. Thus they need to be improved to achieve national target. Malaysia is targetting 500MW (5\% of current electricity demand) of power generation from RE to be gridconnected by end of 8MP (2005); Its only a soft approach. Financing remain one major barrier in smooth progress of the SREP programme. Other challenge to use of biomass for power generation, therefore, is to develop more-efficient, lower-cost systems. Advanced biomass-based systems for power generation require fuel upgrading, combustion cycle improvement, and better fluegas treatment. Future biomass based power. Generation technologies need to provide superior environmental protection at lower cost by combining sophisticated biomass preparation, combustion, and conversion processes with post combustion cleanup. Such systems include fluidized combustion, biomass integrated gasification, and biomass externally fired gas turbines.

\section{REFERENCE}

1. Pusat Tenaga Malaysia, 2005. National BIPV Program "Suria 1000”. http://www.ptm.org.my/bipv/pdf/suria100 0-concept.pdf

2. M. J. Grubb. "The Integration of Renewable Electricity Sources". Energy Policy. 1991. Vol. 19, No. 7.pp 670-688.

3. D. McEvoy, D. C. Gibbs, J. W. S. Longhurst, "City-regions and the Development of Sustainable Energy Supply Systems". Int. J. Energy Res. 2000, 24. pp 215-237.

4. R. Chedid, S. Rahman, "Unit sizing and control of hybrid wind-solar power systems". IEEE Transactions on Energy Conversion. 1997. Vol. 12, No. 1. pp 7985.

5. EC-ASEAN COGEN Program Phase III, December 2004. Malaysia Final Report. Unpublished report Electricity, Windows to Malaysia, 
http://www.windowstomalaysia.com.my/n ation/14_3_1.htm.

6. Intergovernmental Panel on Climate Change, "Greenhouse Gas Inventory Reference Manual", Vol. 3, IPCC WGI Technical Support Unit, United Kingdom, 1995.

7. G. Wiltsee. "Lessons Learned from Existing Biomass Power Plants." NREL/SR-570-26946 Golden, CO: National Renewable Energy Laboratory, February 2000. web site www.nrel.gov/docs/fy00osti/26946.pdf.

8. K.O.Lim, Zainal Alauddin, Z.A,Chulam A, Quadir and Mohd Zulkifly Abdullah, 1999. Energy Productivity of Some Plantation Crops in Malaysia and the Status of Bioenergy Utilizationin Malaysia, Proceedings of World Renewable Energy Congress 1999, pp 3745.

9. F. R. McLarnon, E. J. Cairns, "Energy Storage", Review of Energy, Vol. 14, pp 241-271.

10. Energy Data and Modeling Center, IEEJ, 2005.

http://www.ieej.or.jp/egeda/database/data base-top.html Energy KTM, KTKM, 2005. http://www.ktkm.gov.my.

11. Malaysian Standard, 2005. http://www.aseansec.org/8274.htm MST, 2004. Malaysian-Danish Country Program for Cooperation in Environment and Development (2002-2006), http://www.mst.dk/udgiv/publications/200 1/87-7944-557-8/html/helepubl_eng.htm.

12. G. C. Seeling-Hochmuth, "A combined optimisation concept for the design and operation strategy of hybrid-PV energy systems". Solar Energy. 1997. Vol. 61, No. 2. pp 77-87.

13. RWEDP, 1997. Proceeding of the regional expert consultation on Modern Application of Biomass Energy, No.36.

14. Ahmad Hadri Haris, UNDP, 2004. Biomass-based Power Generation and
Cogeneration in the Malaysian Palm Oil Industry. UNDP, 2004. Malaysia:

15. Michael Brown, 1998. Emission Trading and Joint Implementation: The implications for cogeneration. Cogen Europe, May 1998.

16. Joule-Thermie Programme of the European Commission, "Environmental Aspects of CHPSystems: NOX Abatement Techniques”, United Kingdom, 1997.

17. OECD, Energy and Environmental Technologies to Respond to Global Climate Change Concerns. International Energy Agency. Organisation for Economic Co-operation and Development, France, 1994.

18. World Bank, "Energy Investments and the Environment", ed. C. M. Siddayao, Washington D.C., 1990. World Bank

19. O. O. Sulaiman. (2011) Review on Potential for Waste Recycled Based Bioenergy for Marine System, Int. Journal Environmental Technology and Management (IJETM) Inderscience, Switzerland, Pg 339-357, Vol. 14, Nos 1/2/3/4, 2011, H index (6).

20. O. O. Sulaiman. (2010). Risk And Reliability Based Multi- Hybrid Alternative Energy For Marine System: The Case Of Solar, Hydrogen And Convention Power Steam Energy For Sustainable Port Powering, Jurnal Mechanical, December 2010, No. 31, 7891.

21. O. O. Sulaiman. (2010). Potential Of Biomass Cogeneration For Port Powering Bioscience, Biotechnology Research Asia, Vol 7, No 2, Pg559-578, 2010, SCOPUS , $\mathrm{H}$ Index (3).

22. O. O. Sulaiman. (2011). Techno Economic Study Of Potential Using Solar Energy As A Supporting, International Journal Of Business And Social Science(IJBSS), Centre For Promoting Ideas (CPI), Vol 1, No4, pg 113-119, 2011 IndexCopernicus (9 ), and EBSCOhost. 